\title{
From Conceptualization to Reflection: Ensuring Robust Clinical Experiences While Meeting the Professional Standards for Elementary Special Education Teachers
}

\author{
Sheilah M. Paul* \\ School of Liberal Arts \& Education, Medgar Evers College of CUNY, Bedford Avenue, Brooklyn, NY \\ *Corresponding author: spaul@mec.cuny.edu
}

Received May 17, 2014; Revised February 02, 2015; Accepted February 08, 2015

\begin{abstract}
A major challenge for teacher candidates is meeting the demands of the clinical practice experience which assesses how they make connections between their theoretical knowledge base and the real classroom experience. The critical integration of knowledge of and pedagogy in academic subjects, the use of research-based, scientifically proven strategies and assessment practices, and the understanding of the culturally and linguistically diverse learning needs of students at various developmental levels based on specialty professional standards form the basis for successful teaching and learning. It is this foundation that aids teachers in meeting the multiple teacher licensure requirements across States. Guiding teacher candidates in thinking about, planning, implementing and reflecting on these elements require a systematic approach to clinical practice. This Conceptualization to Reflection Model provides a unique approach for clinical supervisors and cooperating teachers to preparing professional teachers to meet the rigors of the teaching profession. It also serves as a guide for teacher candidates to help them navigate the journey from student to practitioner. Since each teacher preparation program serves a distinct student population, this comprehensive model is presented for one specific degree program: Childhood Special Education (Dual Certificate - Grades 1-6), but can be easily adapted to meet the diverse needs and developmental levels of other student populations.
\end{abstract}

Keywords: pre-service teacher education, special education, clinical practice, student teaching

Cite This Article: Sheilah M. Paul, "From Conceptualization to Reflection: Ensuring Robust Clinical Experiences While Meeting the Professional Standards for Elementary Special Education Teachers.” American Journal of Educational Research, vol. 3, no. 2 (2015): 173-184. doi: 10.12691/education-3-2-10.

\section{Introduction}

With the passage of No Child Left Behind and the Reauthorization of the Individuals with Disabilities Education Improvement Act, the need for "highly qualified teachers" became a front burner issue for teacher preparation programs. Not only are colleges and universities expected to produce teachers to fit the mold of "highly qualified," but they are also required to demonstrate that their education degree programs include extensive practical experiences for teacher candidates (NCATE, 2008, CAEP, 2013). Teacher candidates must acquire and demonstrate that they have the professional knowledge, skills, and dispositions to interact successfully with diverse learning communities. For candidates pursuing special education as a career path, the Council for Exceptional Children requires that "all special educators are well-prepared, career-oriented professionals with the conditions that allow them to provide individuals with exceptional needs the most effective interventions and that encourage entering special educators to become career-oriented special education professionals" (CEC, 2002, Gersten, Keating, Yovanoff, \& Harniss, 2001; Darling-Hammond and Baratz-Snowden, 2005).
Clinical practice experiences, the supervised internship in teacher preparation programs must be "carefully administered, sequenced, and supervised in all areas of the elementary curriculum" and should provide candidates with experiences in a variety of diverse settings. Candidates should also have a broad knowledge base, be adept at creatively using appropriate materials and resources, including technology, and should be able to collaborate effectively with other professionals in the field in order to enhance student learning (ACEI, 2002, 2007).

This clinical practice model for childhood special education teacher candidates is one that is rigorous in many ways. First, it ensures that candidates acquire indepth knowledge of all the critical academic content areas: English Language Arts, Mathematics, Science, Social Studies, the Arts, Health Education and Physical Education to teach students at the elementary school grade levels. To teach all students, teachers need to "understand subject matter deeply and flexibly so they can help students create useful cognitive maps, relate one idea to another, and address misconceptions. Teachers need to see how ideas connect across fields and to everyday life. This kind of understanding provides a foundation for pedagogical content knowledge that enables teachers to make ideas accessible to others" (Shulman, 1987). 
Second, it ensures that all teacher candidates acquire knowledge and skills in special education to meet the needs of diverse and exceptional learners at the elementary level. "Teaching in ways that connect with students also requires an understanding of differences that may arise from culture, family experiences, developed intelligences, and approaches to learning" (Grimmet \& MacKinnon, 1992). To help all students learn, childhood special education teacher candidates need to think about what it means to learn different kinds of material for different purposes and how to decide which kinds of learning are most appropriate in different contexts. Teachers must be able to identify the strengths and weaknesses of different learners and must have the knowledge to work with students who have specific learning disabilities or needs (Shulman, 1992).

A third area of rigor involves a series of early field experiences that precede the clinical practice experience to ensure that candidates know how to collaborate with school partners, design and implement multiple learning and assessment tools, including the use of instructional and assistive technology, and engage in action research and supervised practice with individual and small groups of learners in diverse settings. "Teacher candidates get a more coherent learning experience when they are organized in teams with experienced teachers and college faculty. Experienced teachers deepen their knowledge by serving as mentors and teacher leaders. The early field experiences in partner schools help to create the synergy between theory and practice, while creating the move from the pre-professional to the professional role for candidates as they construct knowledge that is more useful for both practice and ongoing theory building” (DarlingHammond, 1994).

Fourth, the model includes collaborative and interdisciplinary seminars and intercession workshops to enhance candidates' content, pedagogical and professional knowledge, skills and dispositions. Acquiring this sophisticated knowledge and developing a practice that is different from what candidates themselves experienced as students requires learning opportunities for teacher candidates that are more powerful than simply reading and talking about new pedagogical ideas (Ball \& Cohen, 1996). Teachers learn best by studying, by doing and reflecting, by collaborating with other teachers, by looking closely at students and their work, and by sharing what they see. The interdisciplinary seminars provide this professional development experience for pre-service teacher candidates.

The implementation of the New York State Common Core Curriculum and the need to include students with disabilities in schools' assessment and accountability measures require teachers to have knowledge of and ability to teach subject matter (NYCDOE, Raising the Bar for All Students, NY City's Special Education Reform, 2012). In this model, teacher candidates are prepared to teach all four foundational areas: ELA, math, science and social studies that incorporate the Arts, health and physical education components, and are prepared to address all these key areas to support students with both high and low-incidence disabilities in learning across these curricula areas. Candidates acquire a broad scope of interdisciplinary knowledge (12 credits) across academic content areas, then choose a subject area concentration
(27-30 credits), and pass the teaching methods courses (pedagogy) in each subject area.

Content area and specialty workshops for special education pre-service teachers are continuously implemented at Medgar Evers College, and are supported by OSEP funding for personnel preparation since 2007. These extension professional development workshops continue to improve the content knowledge and pedagogical and professional skills of teacher candidates in the academic and non-academic subject areas. Special education collaboration in content area workshops have focused on academics for elementary special education, including lesson planning, adaptation, differentiated instruction, use of assistive and other technological devices, and current research-based practices in teaching and learning, such as Response to Intervention (RTI), Positive Behavioral Intervention and Support, (PBIS), comprehensive assessment practices, and culturally responsive teaching, among others.

The extended workshop curricula are implemented in collaboration with local service providers and district school partners. The curricula include the developmental learning goals identified by the Council for Exceptional Children (CEC) and the Common Core Learning Standards. They are also closely aligned with the Association for Childhood Education International (ACEI) Standards and incorporate the newest ed-TPA framework. These additional workshops, held during the winter and summer intercessions, are non-credit bearing and voluntary and engage candidates prior to, during, and after their clinical practice experience in a relaxed and collaborative mentoring atmosphere.

The need for teachers with subject-matter knowledge, content specialty skills, and enhanced pre-service clinical experiences prompted the development of this model. It responds to the critical need for "highly qualified" teachers to serve students in urban areas that are often characterized by their social and cultural differences. Reports on teacher quality revealed that "students in highpoverty, high minority, and low-performing schools are less likely than other pupils to be taught by teachers trained in their subjects” (Ansell \& McCabe, 2003). They reported that in high-poverty schools, there were $32 \%$ of students who were taught by core teachers without "at least a minor in the subject," compared to $18 \%$ in lowpoverty schools. Data on whether in-service teachers majored or even minored in core subjects they taught were reported in the US Department of Education Schools and Staffing Survey (1999-2000). The results concluded that students in high poverty and high minority schools "get the short end of the stick” (Ansell \& McCabe, 2003).

The need for added preparation in content areas is reflected in the results of the national assessments each year. For students with disabilities, the chances of achieving proficiency in these content areas are even more daunting. Confounding the problem is the fact that most of the schools under review for failure to meet content standards are those schools identified as "high-need" comprised of minority overrepresented groups of students - students with language differences and other socioeconomic disadvantages. The correlation between cultural competency and content knowledge and skills is evident. Medgar Evers College has addressed these issues in its teacher preparation programs and continually evaluates candidates' ability to develop and teach 
developmentally appropriate, culturally and linguistically responsive lessons to students with disabilities in urban schools.

The pinnacle of this preparation is the Clinical Practice experience, which emphasizes the integration of theoretical constructs, acquired knowledge, skills and dispositions into carefully structured supervised experiences that develop the proficiencies required for "highly qualified" teachers. This process provides opportunities for preservice childhood special education teacher candidates to engage in preparing and delivering content-rich and standards-based academic instruction for diverse learners in inclusive and special education settings. To achieve this goal, candidates engage in a process that starts with conceptualization and ends with reflection to demonstrate what they know, understand, and can teach.

\section{Precursor to the Clinical Experience: Early Field Experiences}

Early field experiences provide learning opportunities for candidates to demonstrate increasing involvement in designing, delivering and evaluating instruction prior to their clinical practice experiences. Early field experiences begin with observations of learning professionals and environments, progress to immersion with individual and small groups of learners using and assessing instructional and behavioral interventions and end with active engagement in teaching and learning activities, including interactions with parents, students, teachers and the broader learning community. Early field and clinical experiences and related assessments support candidates' development of themselves as learners and an understanding of the professional field, and their roles as teachers within the field. Field experiences are attached to specific and related courses to contextualize the learning experiences for candidates. These experiences include opportunities to shadow professionals, observation in education, parents and communities as school partners, technology in the classroom, working with individual learners, working with small groups of learners, curriculum research and design and assessment in education.

\section{Length of Clinical Experience and Settings}

As candidates progress from early field to clinical practice, they begin to embrace and articulate the standards of their professional areas. The Clinical Practice experience is extensive and intensive and ensures that candidates have a range of diverse experiences where they can demonstrate the knowledge, skills and dispositions requisite for the specialty field. Childhood Special Education candidates must have a sound foundation of general education knowledge and skills and demonstrate proficiencies in special education knowledge, skills and dispositions so that they can effectively teach all children. To accomplish this complex and sometimes, challenging dual role, childhood special education candidates complete two 14-week semesters (1 year) of Clinical Practice.
Candidates provide instruction in two different settings (Specialized setting or a Cooperative Team Teaching (CTT) classroom during one semester and an Inclusive classroom during the other semester. They also practice teaching students in two different grade levels during these two semesters, a lower grade (1-3) and an upper grade (4-6) in their elementary grade level assignments (Grades 1-6). These experiences serve to broaden the scope of their practical experiences in teaching students with exceptional learning needs. Students in the selfcontained settings include students classified with severe to profound levels of intellectual disabilities, speech/language disorders, autism, traumatic brain injury, cerebral palsy, and other severe and multiple disabilities, whereas students in the inclusive and CTT settings include students with and without mild to moderate forms of sensory, intellectual, physical and emotional/behavioral disorders. Students with disabilities in these settings sometimes include students at age-related multi-grade levels, based on the promotion criteria established at schools. The selection of settings ensures that candidates' clinical experiences include multiple settings to demonstrate their specialty preparation, and meets the extensive requirements for dual-certification.

\section{Placement Decisions}

To ensure that candidates gain the full experience of working with diverse students with a range of disabilities/exceptionalities, the Department's special education clinical faculty and Field and Clinical Coordinator work collaboratively with partner school personnel to select experienced Cooperating Teachers who are licensed and practicing in the field to secure placements for childhood special education candidates. Site visits to schools and classrooms by clinical college faculty are carried out to verify suitability of placements. Conferences are held between cooperating teachers and clinical college faculty to discuss and review program expectations and assessment criteria prior to candidate placements to ensure that cooperating teachers understand their roles and responsibilities as facilitators and mentors for candidates and to establish a committed partnership in giving candidates the best classroom experiences.

\section{Clinical Practice Evaluations}

Evaluation of candidate performance during clinical practice experiences are conducted by both Cooperating Teachers and College Clinical Faculty using rubrics that incorporate the four assessment points identified in the model: Conceptualization/Planning, Implementation, Outcomes and Reflection. Each semester, the childhood special education candidate is formally observed and evaluated during the teaching of four integrated and specific subject area lessons addressing the appropriate Common Core Learning Standards: English Language Arts, mathematics, science, and social studies. In addition, each candidate must produce a videotaped lesson for evaluation. Therefore, over the two semesters of clinical practice, childhood special education candidates are observed at least eight times, and engage in the evaluation 
of two videotaped lessons. After classroom observation of each lesson, the candidate participates in a postobservation conference with both clinical faculty and cooperating teachers to receive feedback on the implementation of the lesson, including feedback on his/her professional dispositions during the observation. Candidates are required to articulate this feedback in reflective essays to demonstrate their understanding of the feedback as well as their openness to using suggestions to improve their future practices.

Table 1. Alignment of Assessment Domains with CEC and ACEI Standards

\begin{tabular}{|c|c|c|c|c|}
\hline $\begin{array}{c}\text { EVALUATION } \\
\text { FORM } \\
\end{array}$ & DOMAINS & $\begin{array}{l}\text { EVALUATION } \\
\text { CRITERIA }\end{array}$ & CEC & ACEI \\
\hline \multirow{10}{*}{$\begin{array}{l}\text { PART I } \\
\text { (Assessment 1) }\end{array}$} & $\begin{array}{l}\text { CONCEPTUALIZATION and } \\
\text { LESSON PLANNING }\end{array}$ & $\begin{array}{l}\text { Central concepts, } \\
\text { tools of inquiry and } \\
\text { structures of } \\
\text { content }\end{array}$ & $\begin{array}{l}\text { CEC 1: Foundations } \\
\text { [CC1K1-CCIK4; CC1K8, } \\
\text { GCIK1-GC1K3] }\end{array}$ & $\begin{array}{l}\text { ACEI 1.0 Development, Learning } \\
\text { and Motivation } \\
\text { ACEI } 3.1 \text { Integrating and } \\
\text { Applying Knowledge for } \\
\text { Instruction }\end{array}$ \\
\hline & \multirow{2}{*}{$\begin{array}{l}\text { Conceptualizing Essay and } \\
\text { Lesson Plan } \\
\text { ed-TPA TASK 1: Planning for } \\
\text { Instruction and Assessment } \\
\text { Context for Learning } \\
\text { Planning Commentary }\end{array}$} & $\begin{array}{l}\text { Development and } \\
\text { Characteristics of } \\
\text { Learners }\end{array}$ & $\begin{array}{l}\text { CEC 2: Development and } \\
\text { Characteristics of Learners } \\
\text { [CC2K1, CC2K2, CC2K5, } \\
\text { CC2K6,GC2K1-GC2K5] }\end{array}$ & $\begin{array}{l}\text { ACEI } 3.2 \\
\text { Adaptation to Diverse Students }\end{array}$ \\
\hline & & $\begin{array}{l}\text { Development } \\
\text { Learning and } \\
\text { Motivation } \\
\end{array}$ & $\begin{array}{l}\text { CEC 3: Individual Learning } \\
\text { Differences } \\
\text { [CC3K1, CC3K2, CC3K5] }\end{array}$ & $\begin{array}{l}\text { ACEI 3.1 Integrating and } \\
\text { Applying Knowledge for } \\
\text { Instruction }\end{array}$ \\
\hline & \multirow{3}{*}{$\begin{array}{l}\text { Lesson Plans for Learning } \\
\text { Segments }\end{array}$} & $\begin{array}{l}\text { Planning and } \\
\text { Designing } \\
\text { Innovative } \\
\text { Learning } \\
\text { Experiences } \\
\end{array}$ & $\begin{array}{l}\text { CEC 4: Instructional Strategies } \\
\text { [CC4K1, GC4K1, GC4K4, } \\
\text { GC4K5, CC4S3, } \\
\text { CC4S4,GC4S7] }\end{array}$ & $\begin{array}{l}\text { ACEI } 3.3 \\
\text { Development of Critical Thinking } \\
\text { and Problem Solving } \\
\text { ACEI } 3.4 \\
\text { Active Engagement in Learning }\end{array}$ \\
\hline & & $\begin{array}{l}\text { Planning and } \\
\text { Designing } \\
\text { Appropriate } \\
\text { Learning } \\
\text { Environments }\end{array}$ & $\begin{array}{l}\text { CEC 5: Learning } \\
\text { Environments and Social } \\
\text { Interactions } \\
\text { [CC5K1-CC5K6; } \\
\text { GC5K2,GC5K3, GC5S1] }\end{array}$ & $\begin{array}{l}\text { ACEI } 3.2 \\
\text { Adaptation to Diverse Students } \\
\text { ACEI } 3.3 \\
\text { Development of Critical Thinking } \\
\text { and Problem Solving }\end{array}$ \\
\hline & & $\begin{array}{l}\text { Effective } \\
\text { Communication }\end{array}$ & $\begin{array}{l}\text { CEC 6: Language } \\
\text { [CC6K4, GC6K2, CC6S1, } \\
\text { CC6S2] }\end{array}$ & $\begin{array}{l}\text { ACEI } 3.5 \\
\text { Communication to Foster } \\
\text { Collaboration }\end{array}$ \\
\hline & Instructional Materials & $\begin{array}{l}\text { Instructional } \\
\text { Planning Methods }\end{array}$ & $\begin{array}{l}\text { CEC 7: Instructional Planning } \\
\text { [CC7K1-CC7K5; GC7K1] }\end{array}$ & $\begin{array}{l}\text { ACEI } 3.1 \\
- \\
\text { ACEI } 3.5\end{array}$ \\
\hline & \multirow{3}{*}{$\begin{array}{l}\text { Assessments and Data Collection } \\
\text { Procedures }\end{array}$} & Assessment & $\begin{array}{l}\text { CEC 8: Assessment } \\
\text { [CC8S1-CC8S5;GC8S3] }\end{array}$ & $\begin{array}{l}\text { ACEI } 4.0 \\
\text { Assessment for Instruction }\end{array}$ \\
\hline & & $\begin{array}{l}\text { Professional and } \\
\text { Ethical Practice }\end{array}$ & $\begin{array}{l}\text { CEC 9: Professional and } \\
\text { Ethical Practice } \\
\text { [CC9K2, CC9S5, CC9S6] }\end{array}$ & $\begin{array}{l}\text { ACEI } 5.1 \\
\text { Professional Growth, Reflection } \\
\text { and Evaluation }\end{array}$ \\
\hline & & Collaboration & $\begin{array}{l}\text { CEC 10: Collaboration } \\
\text { [CC10K1, CC10K4,GC10K4] }\end{array}$ & $\begin{array}{l}\text { ACEI } 3.5 \\
\text { Communication to Foster } \\
\text { Collaboration }\end{array}$ \\
\hline $\begin{array}{c}\text { EVALUATION } \\
\text { FORM } \\
\end{array}$ & DOMAINS & $\begin{array}{c}\text { EVALUATION } \\
\text { CRITERIA } \\
\end{array}$ & CEC ALIGNMENT & ACEI \\
\hline \multirow{7}{*}{$\begin{array}{l}\text { PART II } \\
\text { (Assessment 2) }\end{array}$} & $\begin{array}{l}\text { (A) IMPLEMENTATION } \\
\text { Observation of Instructional } \\
\text { Delivery }\end{array}$ & $\begin{array}{l}\text { Teaching Learners } \\
\text { with Diverse Needs }\end{array}$ & $\begin{array}{l}\text { CEC 2: Development and } \\
\text { Characteristics of Learners } \\
\text { [CC2K1, CC2K2] }\end{array}$ & $\begin{array}{l}\text { ACEI 1.0 Development, Learning } \\
\text { and Motivation }\end{array}$ \\
\hline & $\begin{array}{l}\text { ed=TPA TASK 2: Instructing } \\
\text { and Engaging the Focus Learner }\end{array}$ & $\begin{array}{l}\text { Using Adaptations } \\
\text { for Diverse } \\
\text { Learning } \\
\text { Differences } \\
\end{array}$ & $\begin{array}{l}\text { CEC 3: Individual Learning } \\
\text { Differences [CC3K5] }\end{array}$ & $\begin{array}{l}\text { ACEI } 3.2 \\
\text { Adaptation to Diverse Students }\end{array}$ \\
\hline & Instruction Commentary & $\begin{array}{l}\text { Using Effective } \\
\text { Strategies to } \\
\text { Promote Active } \\
\text { Engagement in } \\
\text { Learning } \\
\end{array}$ & $\begin{array}{l}\text { CEC 4: Instructional Strategies } \\
\text { [CC4S3, GC4S1, GC4S7, } \\
\text { GC4S10] }\end{array}$ & $\begin{array}{l}\text { ACEI } 3.4 \\
\text { Active Engagement in Learning }\end{array}$ \\
\hline & Video Clips & $\begin{array}{l}\text { Practices and } \\
\text { Behaviors of } \\
\text { Developing Career } \\
\text { Special Education } \\
\text { Teachers }\end{array}$ & $\begin{array}{l}\text { CEC 5: Learning } \\
\text { Environments and Social } \\
\text { Interactions [CC5S1, CC5S5, } \\
\text { CC5S15] }\end{array}$ & $\begin{array}{l}\text { ACEI } 5.1 \\
\text { Professional Growth, Reflection } \\
\text { and Evaluation } \\
\text { ACEI } 5.2 \\
\text { Collaboration with Families, } \\
\text { Colleagues and Community } \\
\text { Agencies }\end{array}$ \\
\hline & Video Clips & $\begin{array}{l}\text { Effective } \\
\text { Communication }\end{array}$ & $\begin{array}{l}\text { CEC 6: Language [CC6S1, } \\
\text { CC6S2, CC6K4] }\end{array}$ & $\begin{array}{l}\text { ACEI } 3.5 \\
\text { Communication to Foster } \\
\text { Collaboration }\end{array}$ \\
\hline & Video Clips & $\begin{array}{l}\text { Using Effective } \\
\text { Instructional Plans }\end{array}$ & $\begin{array}{l}\text { CEC 7: Instructional Planning } \\
\text { [CC7S1, CC7S9, GC7S2, } \\
\text { CC7S11, CC7S12, GC7S1, } \\
\text { CC7S13, CC7S15] }\end{array}$ & $\begin{array}{l}\text { ACEI } 3.1 \\
- \\
\text { ACEI } 3.5\end{array}$ \\
\hline & Instruction Commentary & $\begin{array}{l}\text { Using Appropriate } \\
\text { Assessments for } \\
\text { Instruction }\end{array}$ & $\begin{array}{l}\text { CEC 8: Assessment [CC8S2, } \\
\text { CC8S4, CC8S8, GC8S3] }\end{array}$ & $\begin{array}{l}\text { ACEI } 4.0 \\
\text { Assessment for Instruction }\end{array}$ \\
\hline
\end{tabular}




\begin{tabular}{|c|c|c|c|c|}
\hline & $\begin{array}{l}\text { (B) CONTENT AREA } \\
\text { INSTRUCTIONAL METHODS } \\
\text { Observation of Instruction } \\
\text { Instruction Commentary }\end{array}$ & $\begin{array}{l}\text { English Language } \\
\text { Arts }\end{array}$ & $\begin{array}{l}\text { CEC 4: Instructional Strategies } \\
\text { [GC4K7, GC4S4, GC4S11, } \\
\text { GC4S13, GC4S14, GC4S16] } \\
\text { CEC 8: Assessment [CC8S8] }\end{array}$ & $\begin{array}{l}\text { ACEI } 2.1 \\
\text { Reading, Writing and Oral } \\
\text { Language } \\
\text { ACEI } 2.5 \\
\text { The Arts } \\
\text { ACEI } 4.0 \\
\text { Assessment for Instruction }\end{array}$ \\
\hline & Instruction Commentary & Mathematics & $\begin{array}{l}\text { CEC 4: Instructional Strategies } \\
\text { [GC4S5, GC4S7, GC4K6, } \\
\text { GC4S12] } \\
\text { CEC 7: Instructional Planning } \\
\text { [CC7S5, CC7S15] } \\
\text { CEC 8: Assessment [CC8S4, } \\
\text { CC8S8] }\end{array}$ & $\begin{array}{l}\text { ACEI } 2.3 \\
\text { Mathematics } \\
\text { ACEI } 4.0 \\
\text { Assessment for Instruction }\end{array}$ \\
\hline & Instruction Commentary & $\begin{array}{l}\text { Science } \\
\text { Integrated in } \\
\text { Literacy and Math }\end{array}$ & $\begin{array}{l}\text { CEC 4: Instructional Strategies } \\
\text { [CC4S3, GC4S7, GC4S13] } \\
\text { CEC 7: Instructional Planning } \\
\text { [CC7S5, CC7S11] } \\
\text { CEC 8: Assessment [CC8S8, } \\
\text { GC8S3] }\end{array}$ & $\begin{array}{l}\text { ACEI } 2.2 \\
\text { Science } \\
\text { ACEI } 2.6 \\
\text { Health Education } \\
\text { ACEI } 2.7 \\
\text { Physical Education } \\
\text { ACEI } 4.0 \\
\text { Assessment for Instruction }\end{array}$ \\
\hline & Instruction Commentary & $\begin{array}{l}\text { Social Studies } \\
\text { Integrated in } \\
\text { Literacy and Math }\end{array}$ & $\begin{array}{l}\text { CEC 4: Instructional Strategies } \\
\text { [CC4S3, CC4S7, CC4S13] } \\
\text { CEC 7: Instructional Planning } \\
\text { [CC7S8, CC7S11] } \\
\text { CEC 8: Assessment [CC8S8] }\end{array}$ & $\begin{array}{l}\text { ACEI } 2.4 \\
\text { Social Studies } \\
\text { ACEI } 2.5 \\
\text { The Arts } \\
\text { ACEI } 4.0 \\
\text { Assessment for Instruction }\end{array}$ \\
\hline & & $\begin{array}{l}\text { Encourages } \\
\text { Participation }\end{array}$ & CEC 5: CC5S4 & ACEI 3.4 \\
\hline & & $\begin{array}{l}\text { Calls on students } \\
\text { Equally }\end{array}$ & CEC 5: CC5S1 & ACEI 5.1 \\
\hline & & $\begin{array}{l}\text { Offers individual } \\
\text { Help }\end{array}$ & CEC 5: CC5S4 & ACEI 3.2 \\
\hline & & $\begin{array}{l}\text { Waits for Students } \\
\text { to respond }\end{array}$ & CEC 4: CC4S6 & ACEI 3.3, 3.4 \\
\hline & & $\begin{array}{l}\text { Delves deeper into } \\
\text { subject matter }\end{array}$ & CEC 4: CC4S2 & ACEI 3.3 \\
\hline & $\begin{array}{l}\text { (C) DISPOSITIONS } \\
\text { Observed Candidate-Student }\end{array}$ & $\begin{array}{l}\text { Asks higher-level } \\
\text { questions }\end{array}$ & CEC 4: CC4S2 & ACEI 3.3 \\
\hline & Interactions & Gives feedback & CEC 4: GC4S12 & ACEI 3.4, 3.5 \\
\hline & & $\begin{array}{l}\text { Affirms correct } \\
\text { responses }\end{array}$ & CEC 5: GC5S4 & ACEI 3.5 \\
\hline & & $\begin{array}{l}\text { Gives praise and } \\
\text { cites reason for } \\
\text { praise }\end{array}$ & CEC 5: GC5S4 & ACEI 3.5 \\
\hline & & Listens closely & CEC 5: CC5S9 & ACEI 3.5 \\
\hline & & $\begin{array}{l}\text { Accepts students' } \\
\text { feelings }\end{array}$ & CEC 5: CC5S13 & ACEI 5.1 \\
\hline & & Shows respect & CEC 5: GC5S5 & ACEI 5.1, 5.2 \\
\hline & & Is courteous & CEC 5: GC5S5 & ACEI 5.1, 5.2 \\
\hline $\begin{array}{c}\text { EVALUATION } \\
\text { FORM }\end{array}$ & DOMAINS & $\begin{array}{l}\text { EVALUATION } \\
\text { CRITERIA }\end{array}$ & CEC ALIGNMENT & ACEI \\
\hline & $\begin{array}{l}\text { OUTCOMES } \\
\text { Ed-TPA TASK 3: Assessing } \\
\text { Learning } \\
\text { Assessment Commentary }\end{array}$ & Lesson Summary & $\begin{array}{l}\text { CEC 4: Instructional Strategies } \\
\text { [CC4S4] }\end{array}$ & $\begin{array}{l}\text { ACEI } 3.1 \\
- \\
\text { ACEI } 3.5\end{array}$ \\
\hline (Assessment 3) & $\begin{array}{l}\text { Student Data } \\
\text { Completed Final Assessments } \\
\text { Samples of Student Work } \\
\text { Completed Daily Assessment } \\
\text { Records and Baseline Data }\end{array}$ & $\begin{array}{l}\text { Assessment of } \\
\text { Student Learning }\end{array}$ & $\begin{array}{l}\text { CEC 8: Assessment [CC8S5, } \\
\text { CC8S7] }\end{array}$ & $\begin{array}{l}\text { ACEI } 4.0 \\
\text { Assessment for Instruction }\end{array}$ \\
\hline PART IV & $\begin{array}{l}\text { REFLECTION } \\
\text { Reflective Essay } \\
\text { Evidence of Feedback and Use } \\
\text { of Data to Improve Learning }\end{array}$ & $\begin{array}{l}\text { Reflective } \\
\text { Practitioner }\end{array}$ & $\begin{array}{l}\text { CEC 9: Professional and } \\
\text { Ethical Practice [CC9S8, } \\
\text { CC9S9, CC9S11] }\end{array}$ & $\begin{array}{l}\text { ACEI } 5.1 \\
\text { Professional Growth, Reflection } \\
\text { and Evaluation }\end{array}$ \\
\hline (Assessment 4) & $\begin{array}{l}\text { Reflective Essay } \\
\text { Evidence of Feedback and Use } \\
\text { of Data to Improve Learning }\end{array}$ & Collaboration & $\begin{array}{l}\text { CEC10: Collaboration } \\
\text { [CC10S9, GC10K4] }\end{array}$ & $\begin{array}{l}\text { ACEI } 5.2 \\
\text { Collaboration with Families, } \\
\text { Colleagues and Community } \\
\text { Agencies }\end{array}$ \\
\hline
\end{tabular}

The Conceptualization to Reflection Clinical Practice Model for Childhood Special Education candidates encompasses five specific domains with key assessments at four critical points for each observed lesson. Assessment is an integral part of the process as it informs candidates about instructional decision making to improve student learning, evaluates student achievement on various dimensions, and ultimately provides a basis for measuring program effectiveness in teacher preparation. The comprehensive Childhood Special Education Clinical 
Practice Evaluation Form is divided into three major Parts that encompass the four points of evaluation: Part I Conceptualization and Planning, Part II - (a) Implementation, (b) Academic Content Area Methods, and (c) Candidate-Student Dispositions, and Part III Outcomes and Reflection. Inherent in these assessments are the specialty professional standards that childhood special education candidates must meet: the Council for Exceptional Children (CEC) Standards, the Association for Childhood International (ACEI) Standards, and the ed-TPA framework, which are all closely aligned with the Department's evaluation criteria. The following summary table (Table 1) maps the assessment domains and their alignments to professional Standards for Beginning Childhood Special Education Teachers.

These key assessment points reflect the Childhood Special Education clinical practice model, which begins with conceptualizing and planning to teach academic content to students with disabilities, actually teaching those lessons, then assessing student learning and understanding of the content, and using student baseline and performance data to finally reflect on one's competency as a teacher.

\section{Evaluation Instruments}

The Clinical Practice Assessment Form uses the CEC Standards 1 to 10 as the basis for assessing Childhood

Special Education candidates' knowledge, skills and dispositions. In most cases, the assessment is further aligned with specific elements from the Individualized Common Core (ICC) and the Individualized General Curriculum (IGC) for beginning teachers of students with exceptional learning needs. The form is subdivided into four major parts: Conceptualization/Planning, Implementation, Outcomes and Reflection to reflect the key objectives of the clinical practice experience that assesses Childhood Special Education candidates' knowledge, skills and dispositions as well as their effects on student learning.

In planning and teaching integrated subject area lessons for elementary students with disabilities, candidates must first demonstrate their proficiencies in four academic content areas: English Language Arts, mathematics, science and social studies. Subject area assessment rubrics were collaboratively developed by special education and discipline-specific department faculty who teach the content area methods courses to ensure coherence with specialty standards. These rubrics are included in the comprehensive clinical practice assessment instrument and are used to evaluate candidates' knowledge and skills in planning and teaching these critical content areas to students with exceptional learning needs.

\section{The Clinical Practice Model}

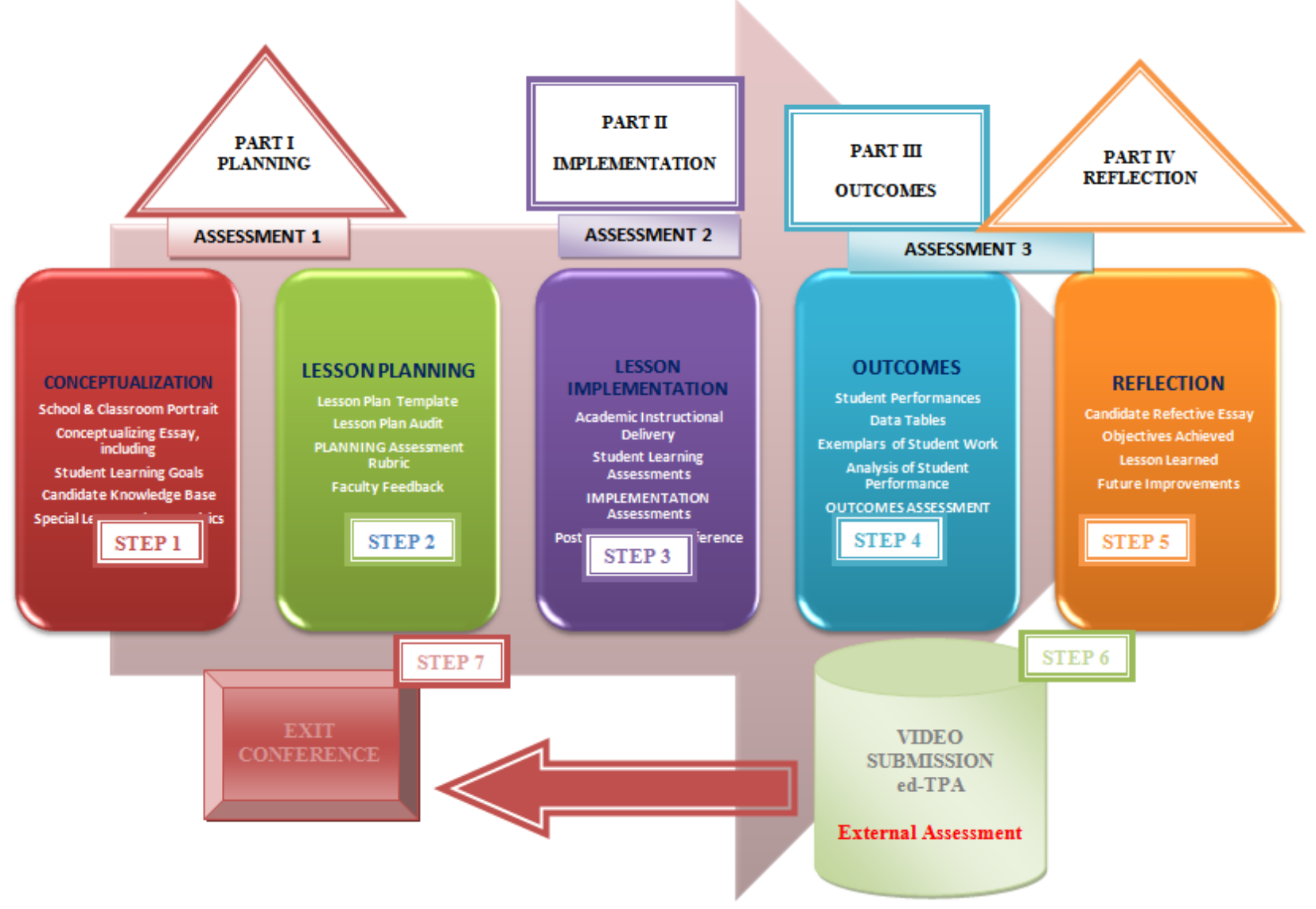

THE CHILDHOOD SPECIAL EDUCATION (CSE) CLINICAL PRACTICE EXPERIENCE MODEL

\subsection{PART I: PLANNING}

STEP 1a: THE CLASSROOM PORTRAIT
Candidates in the Childhood Special Education program are required to submit a School and Classroom Portrait to their College Clinical Supervisor during the first week of Clinical Practice. This Portrait provides a 
snapshot of the setting in which candidates are student teaching and includes details about the school, administration, community, student profiles, resources, and activities. More importantly, the classroom portrait provides information about the characteristics and needs of students so that clinical faculty can accurately judge whether candidates are catering to all the diverse needs of their learners in their conceptualizing and planning of instruction. In addition, a technology inventory informs the clinical faculty and the candidate about the resources available to support their instructional practices or the need to provide additional technology resouces, including assistive and augmentative technoloy to implement lessons.

\section{Components of School and Classroom Portrait}

- Demographics of School/Community

- Demographics of Classroom

- Special Features

- Technology Inventory

\section{STEP 1b: CONCEPTUALIZING ESSAY}

In PART I - Conceptualization, candidates are required to articulate their knowledge of special education content across all of the ten CEC Standards: Foundations, Development and Characteristics of Learners, Individual Learning Differences, Instructional Strategies, Learning Environments and Social Interactions, Language, Instructional Planning, Assessment, Professional and Ethical Practice and Collaboration. This knowledge base must be reflected in candidates' conceptualizing essays and lesson plans to show candidates' understanding of central concepts, tools of inquiry and structures of special education content (CEC 1). Knowledge about the development and characteristics of learners (CEC 2), and the impact of exceptional conditions on development, learning and motivation are requisite to teaching students with the full range of disabilities (CEC 3:). Childhood special education candidates must know evidenced-based instructional strategies to plan and design innovative learning experiences (CEC 4) and must demonstrate knowledge of effective classroom management, behavior interventions and management to meet the individual and collective needs of students (CEC 5). In their conceptualizing essays, candidates' must demonstrate the use of effective communication in articulating their own ideas about teaching and learning and know how to cater to the cultural and linguistic differences found among students in diverse learning environments (CEC 6).

The background knowledge from all the previous standards serves as the foundation on which candidates show their knowledge of instructional planning methods. Candidates must create lessons that give evidence of their knowledge of the Common Core Learning Standards, the City's Scope and Sequence as well as the learning goals for elementary education in the relevant content areas their lessons address. They must show how they use special education principles, such as modifications and accommodations to adapt instruction, including technology enhanced instruction, for their students with disabilities (CEC 7). Candidates must design assessments for each lesson - whether formal or informal, formative or summative - that accurately and fairly assess acquisition of knowledge and skills by diverse students with the full range of disabilities (CEC 8). Childhood Special
Education candidates must articulate in their conceptualizing essays their knowledge of professional and ethical practice, including their respect for diversity, their stance as reflective practitioners and their willingness to explore the various institutions in the field of special education and grow as a professional (CEC 9). Candidates must also discuss their collaborative responsibilities with their cooperating teachers and other school personnel, families and service providers as well as their ongoing consultation with their college supervisors (CEC 10).

The Conceptualizing Essay and Lesson Plan are done simultaneously to comprehensively reflect the thought process used for planning instruction for diverse Elementary school learners. On completing each conceptualizing essay and the lesson plan, the candidate submits these planning documents to their college supervisor who reviews their work, assesses it for readiness to implement and provides feedback to the candidate. The college supervisor uses the prescribed assessment rubric to evaluate the candidate's conceptualizing essay and lesson plan. This evaluation is also formally discussed during the pre-conference meeting between the college supervisor and the candidate to ensure that the candidate is confident about the lesson objectives and teaching points as articulated in the written planning documents, as well as to provide opportunities for clarity of any recommendations made by the college supervisor.

\section{Components of the Conceptualizing Essay}

- The academic content to be learned by the students

- The purpose and use of the content for students

- The Common Core Learning goals addressed in the lesson

- The Candidate's alignment with specialty professional Standards

- The Candidate's knowledge base that influences the lesson (courses, literature, theories, research-based strategies, etc.)

- Any special characteristics about the students that will influence how candidates develop and implement the lesson, e.g. ELL, disability areas, special accommodations, modifications, etc.

\section{STEP 2: LESSON PLANNING}

Childhood Special Education candidates are required to adopt an inclusive stance to planning instruction for their learners. By inclusive, the author posits that a combined focus on general education curriculum content (academic subject areas) as well as individualized curriculum goals (based on the individual learning needs of students) form the basis for instructional planning. The aim of each lesson is to ensure that subject area knowledge is adapted to meet the individual needs of all learners. A recommended lesson plan format helps to guide candidates in addressing all the various components to consider when planning instruction for diverse learners with diverse abilities. This guide also serves as an audit for instructional planning in that it allows candidates to zero in on the key considerations for each lesson.

Recommended Childhood Special Education Lesson Plan Format

Candidate's Name: College Supervisor's Name:

Cooperating Teacher's Name: Clinical Practice Site (i.e., PS XX) 
Date: Time: Grade Level: Components
Room \#

Questions to Guide Your Planning

What are the

I. Standard(s) Being Addressed State Learning Standards you are addressing in this lesson? How does your lesson show evidence of connections between what you are asking students to do and the standard(s) you are addressing?

II. Essential Question Can you think of a global question around which to create your lesson?

III. Teaching Point/Performance What will students learn? What will students do in order to meet the

(GOALS)

IV. Learning Activities

A. Mini Lesson

learning goals? students well? When you do, you can plan learning to build on who they are. How does today's lesson connect to previous learning? How does this lesson anticipate what will come next? What activities/what demonstrations will you structure and design in order to get students involved in learning that will build on who they are? What instructional adaptations are you making to ensure that all your students, including students with disabilities are actively involved in the learning process?

How will the materials/activities/content for learning be introduced to students? How will you demonstrate your teaching point/what you want students to learn?

B. Accountable Talk

What will you ask students to talk about and what will you look for in student's talk that will help you to know whether students are connecting to the Teaching Point/Performance Goals?

C. Guided Practice How will students practice with your assistance or the assistance of peers what they are being asked to learn?

What activities/structures/materials will you provide for students to practice and reach the lesson's goals?

D. Independent Practice How will students practice what they are being asked to learn? What activities/structures/materials will you provide for students to practice independently what they are learning in order to reach the lesson's goals (in the classroom and at home)?

E. Adaptations

What accommodations and modifications will you include in this lesson to meet the individual learning needs of your students?

Accommodations: Highlight the different learning needs of your students and summarize the accommodations you will make based on their individual learning differences.

Modifications: How will you modify guided and independent tasks to meet the needs of your learners?

F. Summary

How will you connect the lesson goal(s) to previous learning and to learning that will continue into the future, so that students can feel they have learned and that what they have learned fits into other learning they have engaged in?

\section{Assessment/Evaluation of}

\section{Learning}

How will you know that all students have learned? What rubric will you use (what are your criteria for learning)? What modifications will you consider in assessing student learning? What activities/materials will you develop that will assist you in assessing what, how and why students learned and reflect the criteria you developed?

How will you reflect on the lesson and assess what occurred?

\section{Feedback and Revisions}

Prior to teaching an observed lesson, candidates meet with both their cooperating teachers and college supervisors to discuss their ideas for each lesson based on their classroom portraits, learning goals and curricula content to be covered by students in their respective settings. Using a Planning Rubric, candidates receive detailed and descriptive feedback from first the Cooperating teacher and then the College Clinical Supervisor on their lesson plans and conceptualizing essays. Candidates use this feedback to make adjustments or revisions accordingly before teaching each lesson. Candidates collaborate with cooperating teachers and college clinical supervisors to schedule observation dates and times for implementation of each lesson.

\subsection{PART II: STEP 3: IMPLEMENTATION OF LESSON}

PART II of the clinical practice assessment includes three subsections that focus on: (a) demonstration of teaching skills, (b) application of developmentally appropriate academic content, and (c) candidate dispositions as they interact with students. These dimensions are aligned mainly with CEC Skill-Based Standards from the CEC Initial Level Skill Sets in the Individualized General Education Curricula (IGC). During observation sessions, Childhood Special Education candidates are evaluated by partner school cooperating teachers and college clinical supervisors on the dimensions listed below.

\section{a. Demonstration of Teaching Skills}

Teaching Students with Diverse Needs - Candidates' lessons must reflect their awareness of the diverse characteristics presented by the students they are teaching and show that they are implementing adequate supports for them [CEC 2: ICC2K1, ICCEK2].

Using Adaptations for Diverse Learning Differences - Candidates' instructional delivery must show how they use individualization, differentiation, accommodations and modifications to meet the individual learning styles and needs of their students [CEC 3: ICC3K5].

Using Effective Strategies to Promote Active Engagement in Learning, including TechnologyEnhanced Instruction - Candidates' lessons must highlight the use of evidence-based effective strategies, including the use of technology to teach requisite academic and nonacademic content. They must demonstrate their 
abilities to select, adapt and use these strategies efficiently to promote active student learning [CEC 4: ICC4S3, 1GC4S1, IGC4S7, IGC4S10].

Practices and Behaviors of Developing Career Special Education Teachers - Candidates' demonstration of teaching students with ELN must reflect their abilities to manage their classrooms effectively using positive behavioral intervention and supports, restating behavior expectations with students, and providing clear instructions for smooth transitions from activity to activity. Candidates must demonstrate positive teacher attitudes towards their students, other teachers and paraprofessionals in the classroom [CEC 5: ICC5S1, ICC5S5, ICC5S15].

Effective Communication - Candidates must model effective language with their students and use communication strategies and resources that promote student understanding of subject matter as well as enhance student communication skills, including the use of alternative and augmentative communication systems, when and where necessary [CEC 6: ICC6S1, ICC6S2, ICC6S4].

Using Effective Instructional Plans - Candidates must show connections to the scope and sequence and identify the learning objectives they are addressing in their lessons based on NY Content Area Curriculum. Their lessons must reflect adaptations of instruction and environment, and incorporation of instructional and assistive technology as needed to meet the individual needs of their students [CEC 7: ICC7S1, ICC7S9, ICC7S11, ICC7S12, ICC7S13, 1CC7S15, IGC7S1, IGC7S2]

Using Appropriate Assessments for Instruction Candidates must demonstrate their use of CurriculumBased Assessments, as well as informal assessments throughout their lessons to monitor students' understanding and mastery of subjects. They must show how they use assessment results, such as anecdotal notes to inform and guide their instruction, and provide feedback to students [CEC 8: ICC8S2, ICC8S4, ICC8S8; IGC8S3].

\section{b. Content Area Knowledge and Skills \\ Application of Developmentally Appropriate Academic Content}

Childhood Special Education candidates must demonstrate proficiencies in teaching general education academic content to students with exceptional learning needs. As such, they must show how they integrate and adapt instruction, assessments and environments, including making appropriate modifications and accommodations to meet the individual needs of their students in Grades 1-6. These considerations are aligned mainly with specific elements from the Individualized Common Core and General Curriculum of CEC Standards 4 - Instructional Strategies, 7- Instructional Planning, and 8-Assessment. Candidates must demonstrate and are evaluated on their abilities to teach lessons in the following four academic content areas, including the use of instructional and assistive technology:

(i) English Language Arts - Candidates must demonstrate the use of reading methods that are appropriate for students with disabilities (IGC4S4) and guide students in identifying and organizing critical information (IGC4K7). They must teach students to use important concepts, vocabulary and content across the general curriculum (IGC4S13) and use strategies and techniques to strengthen and compensate for any deficits in perception, comprehension, memory and retrieval (IGC4S11). When teaching ELA content, candidates must demonstrate the use of systematic instruction to teach accuracy, fluency, and reading comprehension as well as writing (IGC4S14, IGC4S16). CSE candidates must evaluate their teaching of ELA and show how they are monitoring the progress of their students during and after teaching each lesson (ICC8S8).

(ii) Mathematics - The main objective of teaching mathematics to students is to increase their accuracy and proficiency in math calculations and applications (IGC4K6), and as such, CSE candidates must demonstrate the use of appropriate methods to teach mathematics to students with ELN (IGC4S5). Candidates must use appropriate adaptations and technology (IGC4S7), use responses and errors to guide instructional decisions and provide feedback to students (IGC4S12), and use task analysis approaches (ICC7S5) when teaching mathematics content to students with ELN. Candidate must demonstrate ways that they are evaluating and modifying instructional practices in response to ongoing assessment data (ICC7S15), and show their modified and differentiated individualized assessment strategies that they use to evaluate instruction and monitor progress of their students with exceptional learning needs (ICC8S4, ICC8S8).

(iii) Science - In teaching science content, candidates must demonstrate their abilities to select, adapt, and use instructional strategies and materials according to the characteristics of their students with exceptional learning needs (ICC4S3). They must use appropriate adaptations and technology (IGC4S7), and identify and teach essential science concepts, vocabulary, and content across the general curriculum (IGC4S13). Candidates must demonstrate the use of task analysis (ICC7S5), and prepare and organize their materials to implement science lesson plans (ICC7S11). Candidates must develop, modify and use individualized assessment strategies to accommodate the unique abilities and needs of individuals with exceptional learning needs (ICC8S3), and evaluate instruction and monitor progress of their students during their lessons (ICC8S8).

(iv) Social Studies - CSE candidates must demonstrate their abilities to select, adapt, and use instructional strategies and materials to teach social studies content based on the characteristics of their students with exceptional learning needs (ICC4S3). They must show that they are able to develop and select instructional content, resources, and strategies that respond to cultural, linguistic, and gender differences (ICC7S8), use appropriate adaptations and technology (IGC4S7), and identify and teach essential social studies concepts, vocabulary, and content across the general curriculum, including teaching students about diversity (IGC4S13). Candidates must prepare and organize their materials to implement social studies lesson plans (ICC7S11) so that all students are purposefully engaged in the lessons. Candidates must evaluate instruction and monitor progress of their students during their lessons (ICC8S8).

\section{c. Candidate-Student Interactions: Dispositions} Assessment

Candidates are also assessed on 13 dispositions to evaluate their competencies in working with diverse 
students with ELN. The disposition competencies are aligned with CEC Standards 4 and 5, but specifically to elements in the Core Curriculum and the Individualized General Curriculum. Elements in Standard 4 that are addressed assess candidates' modeling of self-assessment, problem-solving and critical thinking strategies as they teach students to use these techniques (ICC4S2) and their ability to modify the pace of instruction and provide organizational cues for students (IGC4S6). Candidates are required to demonstrate the use of student responses and errors to guide their instruction and provide timely feedback to students (IGC4S12). In reinforcing effective candidate-student interactions during instruction, elements of Standard 5 are assessed. Candidates must ensure safe, equitable, positive and supportive learning environments by giving students equal turns (ICC5S1), encourage active participation in individual and group activities by providing individual help, affirming students' correct responses, giving praise and citing the reasons for praise, and teaching students how to give and receive meaningful feedback from others (ICC5S4; IGC5S4). Candidates must model respect and use skills to resolve conflicts (IGC5S5), and create an environment that encourages selfadvocacy, positive intracultural and intercultural experiences for students by listening to them and accepting their feelings (ICC5S9, ICC5S13).

College clinical supervisors and cooperating teachers use a Dispositions rubric below to evaluate childhood special education candidates' dispositions during implementation of each lesson. The goal is to provide adequate feedback on dispositions to candidates so that they can continually grow into their professional roles as teachers.

Table 2. Candidate Dispositions Assessment

\begin{tabular}{|c|c|c|c|c|c|c|}
\hline \multicolumn{7}{|c|}{$\begin{array}{l}\text { Candidate demonstrates the following behaviors during the observation. } \\
\text { (N/A - Not Application; N/O Not observed) }\end{array}$} \\
\hline DISPOSITIONS & $\begin{array}{c}\text { CEC } \\
\text { ALIGNMENTS }\end{array}$ & $\begin{array}{l}\text { Exemplary } \\
\text { (3) }\end{array}$ & $\begin{array}{l}\text { Competent } \\
\text { (2) }\end{array}$ & $\begin{array}{l}\text { Emerging } \\
\text { (1) }\end{array}$ & $\begin{array}{l}\text { Unsatisfactory } \\
\text { (0) }\end{array}$ & COMMENTS \\
\hline $\begin{array}{l}\text { Encourages } \\
\text { participation. }\end{array}$ & ICC5S4 & & & & & \\
\hline $\begin{array}{l}\text { Calls on students } \\
\text { equally. }\end{array}$ & ICC5S1 & & & & & \\
\hline Offers individual help. & ICC5S4 & & & & & \\
\hline $\begin{array}{l}\text { Waits for students to } \\
\text { respond. }\end{array}$ & IGC4S6 & & & & & \\
\hline $\begin{array}{l}\text { Delves deeper into } \\
\text { subject matter. }\end{array}$ & ICC4S2 & & & & & \\
\hline $\begin{array}{l}\text { Asks higher-level } \\
\text { questions. }\end{array}$ & ICC4S2 & & & & & \\
\hline Gives feedback. & IGC4S12 & & & & & \\
\hline $\begin{array}{l}\text { Affirms correct } \\
\text { responses. }\end{array}$ & IGC5S4 & & & & & \\
\hline $\begin{array}{l}\text { Gives praise and cites } \\
\text { reason(s) for praise. }\end{array}$ & IGC5S4 & & & & & \\
\hline Listens closely. & 1CC5S9 & & & & & \\
\hline $\begin{array}{l}\text { Accepts students' } \\
\text { feelings. }\end{array}$ & ICC5S13 & & & & & \\
\hline Shows respect. & IGC5S5 & & & & & \\
\hline Is courteous. & IGC5S5 & & & & & \\
\hline Is courteous. & IGC5S5 & & & & & \\
\hline
\end{tabular}

Disposition rubric adapted from the Los Angeles County Office of Education Teacher Expectations \& Student Achievement (TESA).

OBSERVERS' FEEDBACK - POST OBSERVATION CONFERENCE

A post-observation conference with the candidate, cooperating teacher and the college clinical supervisor is held immediately after each observed lesson to provide feedback to the candidate regarding professional demonstration of instruction for students with exceptional learning needs. Following this conference, candidate must submit reflections on student outcomes based on assessments used during lesson implementation, including samples of student work and data tables. Candidates must also write a reflective essay that summarizes the practical experience and their self-evaluation of their instructional delivery knowledge, skills and dispositions.

\subsection{PART III: POST-OBSERVATION OUTCOMES}

Candidates are encouraged to use assessment data and feedback from observers to reflect on their practices as teachers of students with exceptional learning needs. PART III of the Clinical Practice Assessment focuses on Outcomes of each observed lesson and reflection on student learning. Candidates are required to show how the students' performance data tables from the evaluation of each lesson taught inform them about what children know, learned and need to practice more, about which children master the content taught, which ones are getting it but need more practice, and which students may need a reteaching of the concept. Candidates' extension activities are included so that students gain more opportunities in and beyond the classroom environment to generalize and maintain knowledge of concepts learned. Teacher candidates in conjunction with their cooperating teachers continue to review and incorporate prior knowledge in subsequent lessons to monitor students' progress and to ensure that all students master the content.

By engaging in the above activities, CEC Standards 4, 8, 9 and $\mathbf{1 0}$ are further addressed in candidates' 
assessment and reflections on student work, and on their self-reflections for all eight lessons taught. Having collaborated with their cooperating teachers and, sometimes, grade level curriculum teams (CEC 10: ICC10S9, IGC10K4), candidates must discuss how their assessments confirm children's learning, how children varied in their responses to the assessments and why, and provide possible revisions to the assessments given the results and their own thoughtful critiques (CEC 8: ICC8S5, ICC8S7). In their overall self-reflections, candidates are required to reflect critically on lessons taught to consider how to provide more productive learning opportunities for children and how to shape their own teaching to do so (CEC 9: ICC9S8, ICC9S9, ICC9S11). They must consider in these reflections how the children in their classrooms differ and how that knowledge informs them about using families, colleagues and the larger school community, as well as the larger surrounding community to support children's learning (CEC 4: ICC4S4).

\subsection{PART IV: REFLECTION}

\section{STEP 5a: REFLECTIVE ESSAY}

Childhood Special Education candidates are required to reflect on the outcomes of each lesson. In their reflective essay, candidates discuss the outcomes of the lesson in relation to how they conceptualized and implemented it. They reflect on the feedback from their cooperating teacher and clinical supervisor during the post-observation conference as well as their own feelings about what worked and what they could have done differently. Candidates analyze the student performance data to further understand the impact of their instruction on student learning. They discuss how they will use this information to enhance their own practice and improve student learning in future lessons (CEC 9).

In addition to reflecting on their own teaching and student outcomes, candidates also reflect on other dimensions that influence their clinical experiences, including classroom management practices, their dispositions and their collaboration with classroom personnel. As special educators, teacher candidates are required to demonstrate their ability to work collaboratively with other professionals and support personnel to ensure that all children have appropriate and adequate support and guidance during instruction (CEC 10). They must also demonstrate the appropriate dispositions to promote social learning and engagement among students and show that they know and can use research-based behavior management strategies to maintain a positive learning environment (CEC 5).

\section{STEP 6: TEACHING VIDEO}

One of the most authentic assessments of instructional delivery and its impact on student learning is through the review of videotaped lessons. From 2007, this model emphasized this element of teacher preparation as part of the reflective process. CEC Standards 3, 8, 9 and 10 are further addressed in candidates' assessment and reflections on student work, and on their self-reflections for all four lessons taught. Having collaborated with their cooperating teachers and, sometimes, grade level curriculum teams, candidates must explain how their assessments confirm children's learning, how children varied in their responses to the assessments and why, and provide possible revisions to the assessments given the results and their own thoughtful critiques. In their overall self-reflections, candidates are required to reflect critically on lessons taught to consider how to provide more productive learning opportunities for children and how to shape their own teaching to do so. They must consider in these reflections how the children in their classrooms differ and how that knowledge informs them about using families, colleagues and the larger school community, as well as the larger surrounding community, to support children's learning.

Candidates are required to videotape two lessons they conduct over the one-year experience of Clinical Practice. In the past, the videos were watched only by candidates and their college supervisors. During January 2008 semester in which candidates attended winter intercession workshops provided through a US Department of Education Office of Special Education Programs (OSEP) grant, entitled "Preparing a New Cadre of Special Educators" (PANCOSE), the videos were used as a way to reflect on the first semester of clinical practice before candidates proceeded to their second semester-long experience. There was great success with this, and this practice was incorporated into the model so that this video critique and deconstruction became a regular part of all candidates' learning.

Videos are accompanied by a copy of the candidates' lesson plans, so that candidates can talk about and reflect on the relationship between planning and implementation. However, the entire video is viewed so that candidates can talk about motivation in learning, classroom climate, lesson and demonstration effectiveness, and dispositions. Candidates also learn how to talk critically about teaching and learning. This kind of critique is used constructively to improve teaching not to destroy the confidence of the candidate. All of this has had a positive effect on how well candidates are learning to teach: viewing videos together brings out the areas for explicit assessment, so that everyone is privy to this knowledge and candidates are exposed to how their peers teach. Such knowledge assists their own teaching by providing positive models and ways to reimagine what candidates already can do.

\section{STEP 7: PORTFOLIO PRESENTATION AND EXIT CONFERENCE}

The Exit process is the informal discussion between each candidate and clinical faculty about the overall clinical experience and includes the candidate's evaluation of placement sites and their cooperating teachers. It is where candidates provide evidence of their knowledge, skills, and dispositions related to professional practice of teaching and learning. They review their lesson packets, student outcomes data, the feedback from cooperating teachers and clinical faculty, their prior reflections on the observed lessons and write a new reflective essay of their growth in the professional field. This self-evaluation also includes their assessment of how they met professional standards based on their respective specialty organizations, always with the constructive eye on lessons learned and areas for improvement. 


\section{Summary}

The Conceptualization to Reflection Clinical Practice model for teaching students with exceptional learning needs in the elementary classroom has proven to be a useful tool is the evaluation of teacher candidates' knowledge, skills and dispositions in the following ways:

1. It shows candidates' ability to think deeply about appropriate and effective instruction for diverse learners; 2. It shows candidates' own knowledge of subject matter as they prepare lessons in all critical academic content areas;

3. It shows candidates' ability to connect theory to practice as they utilize some of the scientifically proven approaches and research-based strategies for teaching students with various disabilities;

4. It reflects candidates' attitudes towards teaching students with disabilities in various settings and under practical, real-life circumstances; and

5. It reflects candidates' ability to work collaboratively with others in the entire school community to meet the needs of ALL students.

With the recent adoption of ed-TPA (2013) as a New York State requirement for initial teacher certification, this model was well ahead of the curve in adopting frameworks for assessing effective teaching. Candidates will already have had the experience of conceptualizing and contextualizing the art of teaching, receiving and giving constructive critique and engaging in reflection on and about their formal evaluations of their teaching. These practices have led to increased recruitment, hiring and retention of dual-certified teachers graduating from Medgar Evers College into public and charter schools serving students with disabilities. According to Ronfeldt (2012), "Teachers who learned to teach in field placement schools with higher proportions of black, poor, and low achieving students were no more or less effective as permanent teachers, nor likely to remain teaching in NYC schools." However, the College's emphasis on serving these underserved groups contributes to the consistent pattern of recruitment and retention of its teachers in Central Brooklyn and environs. From 2008 to 2013, 90$95 \%$ of graduates gained employment in these urban schools and retained their positions while 80-85\% continued graduate studies towards the professional licensure and tenure track.

This Conceptualization to Reflection Clinical Practice model was piloted in 2004 and was tested and revised over the years as feedback from cooperating teachers, partner schools, candidates, clinical faculty and professional accreditation organizations helped to refocus and refine the assessment instruments. The result of this continuous improvement in the clinical practice experiences for special education teacher candidates is the very intensive and comprehensive process that takes teacher candidates from conceptualization to reflection over a one-year period of on-site supervised teaching practice, working with diverse learners in different settings in urban schools.

\section{References}

[1] Ansell, S. C., \& McCabe, M. (2003). To close the gap, quality counts: Off target. Quality Counts-Education Week, Vol. 22 (17) p7, 57-58.

[2] Association for Childhood Education International. (1998-2002). Position Paper: Preparation of Elementary Teachers. Author. Retrieved on October, 12, 2014 from http://www.acei.org.

[3] Ball, D. L., \& Cohen, D. K. (1996). Reform by the book: What is-or might be--the role of curriculum materials in teacher learning and instructional reform? Educational Researcher, 25(9), 6-8.

[4] Council for the Accreditation of Educator Preparation [CAEP]. (2013). CAEP Accreditation Standards and Recommendations. Washington, DC: Authors.

[5] Council for Exceptional Children. (2002). NCATE/CEC program standards, preparation of special education teachers. Arlington, VA: Authors.

[6] Darling-Hammond, L., \& Baratz-Snowden, J. (Eds.). (2005). A good teacher in every classroom: Preparing the highly qualified teachers our children deserve, pp. 38-39. San Francisco, CA: Jossey-Bass.

[7] Darling-Hammond, L. (1994). Will 21st-century schools really be different? The Education Digest, 60, 4-8.

[8] Elliott, E. (Ed.). (2003). Assessing education candidate performance: A look at changing practices. Washington, DC: National Council for Accreditation of Teacher Education.

[9] Gersten, R., Keating, T., Yovanoff, P., \& Harniss, M. K. (2001). Working in special education: Factors that enhance special educators' intent to stay. Exceptional Children, 67(4), 549-567.

[10] Grimmet, P., \& MacKinnon, A. (1992). Craft knowledge and the education of teachers. In G. Grant Ed.), Review of Research in Education 18, pp. 59-74, Washington, DC: AERA.

[11] Ladson-Billings, G. (1995). But that's just good teaching! The case for culturally relevant pedagogy. Theory into Practice, 34(3), 159165.

[12] Marzano, R. J., Pickering, D. J., \& Pollock, J. E. (2001). Classroom instruction that works: Research-based strategies for increasing student achievement. Alexandria, VA: Association of Supervision and Curriculum Development.

[13] National Council for Accreditation of Teacher Education [NCATE]. (2010). Transforming teacher education through clinical practice: A national strategy to prepare effective teachers. Washington, D. C.: Author.

[14] New York City Department of Education. (2012). Raising the bar for all students: New York City's special education reform. Author. Retrieved on October 3, 2014 from http://www.nycdoe.gov.

[15] Ornstein, A. C., Thomas, J., \& Lasley, I. (2000). Strategies for effective teaching. New York: McGraw-Hill.

[16] Ronfeldt, M. (2012). Where should student teachers learn to teach? Effects of field placement school characteristics on teacher retention and effectiveness. Educational Evaluation and Policy Analysis, 34:1, 3-26.

[17] Shulman, L. (1987). Knowledge and teaching: Foundations of the new reform. Harvard Educational Review, 57 (1), 1-22.

[18] Shulman, L. (1992, September-October). Ways of seeing, ways of knowing, ways of teaching, ways of learning about teaching. Journal of Curriculum Studies, 28, 393-396.

[19] Tomlinson, C. A. (2003). Fulfilling the promise of the differentiated classroom: Strategies and tools for responsive teaching. Alexandria, VA: Association of Supervision and Curriculum Development.

[20] University of Northern Iowa, Intime. (1999-2002). Retrieved September 27, 2014 http://www.intime@uni.edu.

[21] Wiggins, G. P. (1998) Educative assessment: Designing assessments to inform and improve student performance. San Francisco: Jossey-Bass. 